\title{
Ketaatan Akuntansi, Kontrol Atasan, Budaya Etis Organisasi, Penegakan Hukum dan Kecurangan Akuntansi
}

\author{
Intan Putri Estikasari ${ }^{1}$, Priyo Hari Adi² \\ 1,2, Universitas Kristen Satya Wacana , Salatiga, Indonesia
}

\section{INFO ARTIKEL JEL Classification : M41, D73}

Keywords : compliance to accounting rule, supervisior control, organization's culture ethic, law enforcement, accounting fraud

\begin{abstract}
The purpose of this research is to examine the influence of compliance to accounting rules, supervisior control, organization's culture ethic and law enforcement toward accounting fraud. The population in this study are all Regional organization in Salatiga city (Opd). The sample in this study using technigue total sampling. The data collection technique has been done by issuing questionnaires. The testing of the influences of independent variables toward dependent variables was done by using multiple linear regressions model. Based on each variable in the study, compliance to accounting rules, supervisior control, organization's culture ethic and law enforcement have a significant negative influence to the accounting fraud.
\end{abstract}

\begin{abstract}
ABSTRAK
Penelitian ini bertujuan untuk menguji ketaatan aturan akuntansi, kontrol atasan, budaya etis organisasi dan penegakan hukum dan kecurangan akuntansi. Populasi dalam penelitian ini semua Organisasi Perangkat Daerah (OPD) di kota Salatiga. Sampel penelitian ini menggunakan teknik total sampling. Data dikumpulkan dengan menyebarkan kuesioner. Pengujian pengaruh variabel independen terhadap variabel dependen dilakukan dengan menggunakan model regresi linier berganda. Berdasarkan masing-masing variabel dalam penelitian, kepatuhan terhadap aturan akuntansi, kontrol atasan, budaya etis organisasi dan penegakan hukum memiliki pengaruh negatif signifikan terhadap kecurangan akuntansi.
\end{abstract}

\section{Pendahuluan}

Organisasi Perangkat Daerah (OPD) adalah unit organisasi di pemerintah daerah yang membantu menjalankan roda pelayanan publik. Dalam melakukan tugas pelayanan publik, OPD memperoleh alokasi dana yang berupa anggaran dan juga barang atau aset. OPD merupakan salah satu unit organisasi daerah yang melaksanakan prosedur akuntansi berupa analisis transaksi, pencatatan serta penyusunan laporan keuangan sebagai bentuk tanggung jawab pengelolaan keuangan daerah yang akan disampaikan kepada kepala daerah. Namun dalam praktik prosedur akuntansi yang dilakukan aparatur pemerintah daerah banyak kecurangan akuntansi yang terjadi. Kecurangan adalah usaha yang dilakukan untuk memperoleh keuntungan pribadi dan merugikan pihak lain. Kecurangan pada hakikatnya adalah tindakan yang disusun dansengaja dilakukan untuk menguasai harta atau hak milik pihak lain (Aranta, 2013).

Kasus kecurangan yang sering terjadi salah satunya adalah korupsi dengan modus penyalahgunaan anggaran. Anggaran merupakan gambaran kinerja yang akan diperoleh suatu lembaga dalam satuan 
finansial (Amalia, 2015). Dari awal sampai pertengahan tahun 2018 ditemukan 39 kasus penyalahgunaan anggaran, dengan nilai kerugian negara sebanyak Rp. 86.500.000.000 (ICW, 2018). Anggaran merupakan suatu yang rentan akan kecurangan, karena kecurangan terhadap anggaran tidak hanya terjadi pada saat pelaksanaan anggaran, namun dapat terjadi diawal saat penyusunan anggaran. Aranta (2013) Kecurangan akuntansi yang terjadi dipengaruhi oleh beberapa hal diantaranya keserakahan Greed (keserakahan), Opportunity (kesempatan), Need (kebutuhan) dan Exposure (pengungkapan).

Ketaatan aturan akuntansi adalah tindakan disiplin terhadap aturan akuntansi yang berjalan dalam organisasi. Pemerintah daerah menggunakan Standar Akuntansi Pemerintah (SAP). Penelitian oleh Indriastuti, Agusdin dan Aminah (2016) menunjukkan ketaatan aturan akuntansi memiliki pengaruh negatif terhadap kecurangan akuntansi. Dengan demikian semakin tinggi ketaatan terdahap aturan akuntansi dalam sebuah organisasi, maka semakin sedikit potensi terjadinya kecurangan dalam organisasi tersebut.

Selain ketaatan aturan akuntansi kontrol atasan dalam bentuk pengendalian, pengawasan serta pemeriksaan merupakan salah satu penyebab yang dapat mempengaruhi kecurangan. Arisandy (2004) menjelaskan saat seorang atasan menjalankan kontrol terhadap bawahannya dengan benar, dengan demikian fungsi kontrol dalam suatu organisasi akan berjalan sebagaimana mestinya sehingga suatu organisasi dapat melaksankan tujuan sesuai aturan yang berlaku dengan demikian dapat meminimalisir adanya kecurangan.

Penelitian Rizky dan Fitri (2017) menggunakan penegakan hukum sebagai variabel yang mempengaruhi kecuranganakuntansi. Dalam penelitian tersebut penegakan hukum memiliki pengaruh negatif terhadap kecurangan akuntansi, penegakan hukum yang semakin baik dalam setaip oraganisasi maka potensi kecurangan akan makin berkurang. Penegakan hukum merupakan tindakan nyata yang harus berlaku dalam sebuah organisasi, disertai kesadaran anggota organisasi terhadap hukum karena kebanyakan orang mengerti akan hukum namun tidak mematuhinya (Faisal, 2013).

Terjadinya kecurangan akuntansi juga dapat dipengaruhi oleh budaya etis organisasi. Penelitian Noviriantini, Darmawan, dan Werastuti (2015) mengemukakan bahwa budaya etis organisasi berpengaruh negatif terhadap kecurangan akuntansi. Artinya, bila budaya etis organisasi yang baik diterapkan, maka kecurangan akuntansi akan berkurang. Budaya organisasi yang baik akan menjadi pencegah seseorang untuk berperilaku menyimpang, dengan budaya baik yang ditanamkan sejak dini akan membuat seseorang untuk berpikir kembali saat akan melakukan kecurangan. Oleh karena itu penelitian ini memilih budaya etis organisasi sebagai salah satu variabel penelitian, untuk melihat seberapa jauh budaya etis organisasi dalam mempengaruhi kecurangan akuntansi.

Sesuai uraian diatas peneliti ini akan menguji bagaimana ketaatan aturan akuntansi, kontrol atasan, penegakan hukum dan budaya etis organisasi dapat mempengaruhi kecurangan akuntansi. Penelitian ini bertujuan untuk mendapatkan bukti empiris apakah ketaatan terhadap aturan akuntansi, kontrol atasan, penegakan hukum serta budaya etis organisasi berpengaruh terhadap kecurangan akuntansi. Hasil penelitian ini diharapkan dapat berguna sebagai pengetahuan dan referensi bagi penelitian selanjutnya.

\section{Telaah Teori dan Pengembangan Hipotesis}

\section{Definisi Variabel}

Menurut Rizky dan Fitri (2017) Ketaatan aturan akuntansi merupakan keharusan untuk setiap anggota organisasi dalam mengikuti setiap aturan akuntansi dalam menyusun laporan keuangan agar tranparansi danakuntabilitas pengolahan keuangan dapat tercipta. Ketaatan aturan akuntansi dianggap sebagai tingkat kesesuaian metode pengolahan aset dalamsuatu organisasi, pelaksanaan prosedur akuntansi, serta penyajian laporan keuangan yang didukung dengan bukti pembantunya sesuai standar yang telah ditentukan. Dalam standar akuntansi yang telah ditentukan terdapat aturan yang harus digunakan. Pemerintah menggunakan Standar Akuntansi Pemerintahan (SAP) sebagai acuan 
dalam menyusun dan menyajikan laporan keuangan pemerintah yang diatur dalam Peraturan Pemerintah nomor 71 tahun 2010 tentang Standar Akuntansi Pemerintahan (SAP) dengan maksud meningkatkankualitas pertanggungjawaban kinerja pemerintah.

Kontrol atasan merupakan segala upaya atau perbuatan yang dilakukan oleh atasan dengan tujuan untuk melihat kenyataan yang sebenarnya perihal pelaksanaan tugas dan kegiatan dalam sebuah organisasi (Arisandy, 2004). Kontrol yang dilakukan atasan dapat memberikan persepsi bagi pegawai, setiap pegawai akan memiliki persepsi yang berbeda-beda. Apabila atasan melakukan arahan serta pemeriksaan terhadap kinerja pegawai dalam suatu organisasi maka pegawai akan memiliki persepsi positif dengan demikian akan berdampak pada perilaku pegawai yang bekerja sebagaimana mestinya. Namun, saat atasan tidak melakukan fungsi kontrol dengan baik dalam artian tidak memberikan arahan, pemeriksaan terhadap kinerja pegawai serta tidak melakukan tindakan tegas atas tindakan menyimpang yang dilakukan pegawai, maka akan timbul persepsi negatif dari pegawai sehingga menimbulkan perilaku tidak disiplin atau bekerja tidak sebagaimana mestinya

Budaya Etis Organisasi tumbuh dan dikembangkan dari diri individu yang melaksanakan tugas dan tanggungjawab terhadap sebuah organisasi sebagai pedoman bagi pegawai dalam melakukan pekerjaan serta nilai yang dipertahankan dan merupakan faktor pembeda antara organisasi (Sari, 2018). Budaya organisasi merupakan pemaknaan serta sistem yang dipegang oleh anggota dalam suatu organisasi, yang mana berisikannilai-nilai serta norma yang membentuk karakter atau perilaku seseorang dalam berorganisasi (Artini, Adiputra, dan Herawati, 2014). Budaya organisasi menyebabkan pengaruh yang besarterhadap pembentukan perilaku yang sesuai etika, karena budayaorganisasi berfungsi untuk membimbing tindakan yang dilakukan oleh anggota organisasi. Dengan demikian budaya organisasi dapat mendorong sesorang untuk bertindak etis yang berdampak pada penghindaran terhadap perbuatan yang dapat merugikan oraganisasi.
Penegakan hukum dalam arti luas merupakan bentuk tindakan atau aktifitas yang bertujuan supaya hukum dapat dijadikan sebagai alat untuk mengatur dan mengikat dalam setiap dimensi hidup bermasyarakat dan bernegara dan menindak setiap pelanggaran undang-undang atau perbuatan yang melanggar hukum yang salah satunya merupakan kecurangan, sehingga hukum merupakan alat yang begitu penting demi meminimalisir kecurangan (Rizky dan Fitri, 2017).

Menurut IAI dalam Adelin (2013) kecurangan akuntansi yaitu salah saji atau dengan sengaja menghilangkan jumlah atau pengungkapan dalam laporan keuangan yang dapat mengecoh pengguna laporan keuangan, serta salah saji yang muncul karena perilaku tidak semestinya atas aktiva atau berkaitan dengan pencurian aktiva yang berdampak laporan keuangan tidak disajikan berdasarkan prinsip akuntansi yang berlaku di Indonesia. Jenis kecurangan yang umum terjadi menurut (Sumbayak, 2017) yang pertama merupakan manipulasi atau mengubah catatan serta dokumen. Kedua, Pencatatan transaksi fiktif. Ketiga, secara sengaja menghilangkan transaksi yang seharusnya dicatat. Keempat, melakukan kesalahan dalam penerapan kebijakan akuntansi dan yang terakhir kegagalan dalam mengungkapkan informasi.

\section{Pengembangan Hipotesis}

\section{Pengaruh Ketaatan Aturan Akuntansi terhadap Kecurangan Akuntansi}

Ketaatan lahir dari diri individu sendiri yang mendorong individu tersebut untukmelakukan sebuah tindakan. Tindakan tersebut merujuk pada sesuatu yang akan didapat individu atau keuntungan yang mungkin diterima. Seorang individu akan memiliki niat untuk tidak taat terhadap aturan akuntansi, saat ia yakin bahwa tindakan yang ia lakukan akan menghasilkan keuntungan bagi dirinya sendiri walaupun melalui tindakan curang. Oleh karena itu ketaatan akuntan akuntansi diyakini dapat mempengaruhi adanya kecurangan.

Penelitian oleh Rizky \& Fitri (2017) dan Ade (2017) menyatakan ketaatan aturan akuntansi berpengaruh negatif terhadap kecurangan akuntansi. Semakin baik tanggungjawab pegawai terhadap 
pekerjaannya yang didukung konsistensi melaksanakan aturan akuntansi (SAP) yang berlaku maka kesalahan hingga kecurangan dapat diminimalisir. Dari pernyataan dan penelitian terdahulu, maka dirumuskan hipotesis sebagi berikut:

$\mathrm{H}_{1}$ : Ketaatan aturan akuntansiberpengaruh negatif terhadapkecurangan akuntansi

\section{Pengaruh Kontrol Atasan terhadap Kecurangan Akuntansi}

Kontrol atasan adalah upaya yang dilakukan atasan untuk mengendalikan dan mengatur pelaksanaan tugas dalam organisasi. Kontrol yang dilakukan atasan akan mempengaruhi seorang individu dalam bertindak, semakin intensif kontrol yang dilakukan atasan akan membuat bahawan bertindak sebagaimana mestinya. Pengawasan yang sering dilakukan oleh atasan akan membuat bawahan merasa enggan saat ingin melakukan tindakan yang tidak sesuai aturan sehingga kecurangan yang mungkin terjadi karena tindakan yang tidak sesuai aturan akan berkurang. Penelitian oleh Soleha, Komara \& Sudia (2012) menjelaskan bahwa kontrol atasan yang baik maka akan tumbuh mental yang terbina dari diri bawahan, sehingga akan berdampak pada perilaku etis yang tercermin dalam tugas dan tanggungjawab bawahan dalam kegiatan operasional organisasi. Dari pernyataan diatas dirumuskan hipotesis sebagai berikut :

$\mathrm{H}_{2}$ : Kontrol atasan berpengaruh negatif terhadap kecurangan akuntansi.

\section{Pengaruh Budaya Etis Organisasi terhadap Kecurangan Akuntansi}

Budaya etis organisasi juga berfungsi untuk membimbing tindakan yang dilakukan oleh anggota organisasi dan menjadi pedoman bagaimana seorang pegawai harus bertindak (Sari, 2018). Jika berkembang budaya organisasi yang buruk, maka seseorang akan lebih mudah melakukan kecurangan, budaya organisasi yang pegawainya menganggap kecurangan merupakan hal yang wajar maka pegawai akan tetap menjalankan pembenaran tersebut dalam melakukan tugasnya setiap hari. Sebaliknya, jika berkembang budaya organisasi yang baik maka akan meminimalkan kecenderungan kecurangan yang akan terjadi. Jika sedari awal budaya organisasi menanamkan nilai bahwa kecurangan sekecil apapun merupakan perbuatan yang tidak benar dan akan merugikan pihak lain, maka kecurangan yang dilakukan oleh para pegawai akan semakin berkurang.

Penelitian Artini, Adipura, \& Herawati (2014) dan Pramudita (2013) menyatakan bahwa budaya etis organisasi berpengaruh negatif terhadap kecurangan akuntansi. Budaya etis organisasi yang baik akan mendorong anggota organisasi bertindak sesuai etika, dengan demikian kecurangan akan semakin berkurang. Dalam penelitian tersebut budaya etis dapat mengungkapkan seberapa baik peraturan organisasi dijalankan serta bagaimana kecurangan dapat dihindari. Dari pernyataan dan penelitian terdahulu yang telah dilakukan, maka dirumuskan hipotesis berikut ini:

$\mathrm{H}_{3}$ : Budaya etis organisasi berpengaruh negatif terhadap kecurangan akuntansi.

\section{Pengaruh Penegakan Hukum terhadap Kecurangan Akuntansi}

Menurut Faisal (2013) penegakan hukum dalam organisasi dapat berjalan dengan efektif saat adanya kesadaran dari anggota organisasi, kesadaran tersebut lahir dari diri seseorang secara alamiah. Jika seseorang sadar hokum dan mengerti bahwa tindakan curang akan membuat dirinya merasa tidak aman, tidak tenang serta dikuasai rasa bersalah maka ia akan berusaha menaati hokum dengan menghindari kecurangan. Namun, saat seseorang menganggap hukum merupakan hal yang mudah dilanggar maka ia akan cenderung bertindak tidak sebagaimana mestinya atau bertindak menyimpang. Oleh karena itu penegakan hokum diyakini dapat mempengaruhi kecurangan akuntansi.

Penelitian Faisal (2013) dan Sari (2018) mengatakan bahwa penegakan hukum berpengaruh negatif terhadap kecurangan akuntansi. Hukum yang semakin ditegakkan maka kecurangan yang mungkin terjadi akan semakin berkurang. Dari pernyataan dan penelitian terdahulu yang telah dilakukan, maka dirumuskan hipotesis berikut ini:

$\mathrm{H}_{4}: \begin{aligned} & \text { Penegakan } \\ & \text { negatif } \\ & \text { akuntansi. }\end{aligned}$
terhadap




\section{Metode Penelitian}

Penelitian ini adalah penelitian yang meneliti hubungan antara dua variabel atau lebih atau biasa disebut penelitian kausatif. Penelitian ini menggunakan organisasi pemerintahan Kota Salatiga yang berjumlah 30 Organisasi Perangkat Daerah (OPD) sebagai populasi. Sedangkan, sampel yang digunakan merupakan sampel secara keseluruhan atau biasa disebut total sampling. Data didapatkan dari teknik penelitian dengan menggunakan kuisioner serta wawancara langsung kepada staf akuntansi di masingmasing OPD Kota Salatiga. Instrumen yang digunakan untuk mengukur masing-masing variabel berupa kuisioner yang diukur dengan menggunakan model skala likert.

Tabel 1. Indikator Empiris Dari Ketaatan Aturan Akuntansi, Kontrol Atasan, Penegakan Hukum, Budaya Etis Organisasi dan Kecurangan Akuntansi

\begin{tabular}{|c|c|c|}
\hline Variabel & Definisi Operasional & Indikator \\
\hline $\begin{array}{l}\text { Ketaatan Aturan } \\
\text { Akuntansi X1 }\end{array}$ & $\begin{array}{l}\text { Ketaatan aturan akuntansi merupakan } \\
\text { keadaan dimana anggota organisasi } \\
\text { melakukan prosedur akuntansi sesuai dengan } \\
\text { aturan yang berlaku (Rizky \& Fitri, 2017). }\end{array}$ & $\begin{array}{l}\text { 1. Tanggung jawab penerapan, aturan yang berlaku } \\
\text { (SAP) } \\
\text { 2. Kejujuran dalam pelaksanaan prosedur akuntansi } \\
\text { 3. Objektivitas } \\
\text { 4. Kehati-hatian } \\
\text { 5. Kerahasiaan } \\
\text { 6. Konsistensi } \\
\text { 7. Standar teknis }\end{array}$ \\
\hline Kontrol Atasan X2 & $\begin{array}{l}\text { Kontrol atasan merupakan tindakan atau } \\
\text { upaya yang dilakukan atasan untuk } \\
\text { mengendalikan dan mengatur pelaksanaan } \\
\text { tugas dalam organisasi (Arisandy, 2004). }\end{array}$ & $\begin{array}{l}\text { 1. Pengendalian oleh atasan } \\
\text { 2. Komunikasi antar atasan dan bawahan } \\
\text { 3. Pengawasan oleh atasan terhadap kinerja bawahan }\end{array}$ \\
\hline Budaya Etis Organisasi X3 & $\begin{array}{l}\text { Budaya etis organisasi merupakan dasar, } \\
\text { norma, kaidah dan kepercayaan yang dianut } \\
\text { oleh anggota organisasi untuk yang } \\
\text { digunakan sebagai pedoman berorganisasi } \\
\text { (Sari, 2018). }\end{array}$ & $\begin{array}{l}\text { 1. Di dalam organisasi perilaku etis bukan menjadi } \\
\text { hal yang diutamakan } \\
\text { 2. Adanya sikap toleran terhadap tindakan yang tidak } \\
\text { etis } \\
\text { 3. Teguran/sangsi atas perilaku tidak etis }\end{array}$ \\
\hline Penegakan Hukum X4 & $\begin{array}{l}\text { Penegakan hukum merupakan penindakan } \\
\text { atas tindakan yang melanggar hukum yang } \\
\text { bersifat mengikat dan mengatur (Faisal, } \\
\text { 2013). }\end{array}$ & $\begin{array}{l}\text { 1. Peraturan organisasi } \\
\text { 2. Disiplin kerja } \\
\text { 3. Tanggung jawab } \\
\text { 4. Kesadaran akan hukum }\end{array}$ \\
\hline Kecurangan Akuntansi Y & $\begin{array}{l}\text { Kecurangan Akuntansi merupakan penipuan } \\
\text { di bidang akuntansi yang dilakukan secara } \\
\text { sengaja yang bermaksud untuk mengambil } \\
\text { aset atau hak milik pihak lain (Tunggal, } \\
\text { 2012). }\end{array}$ & $\begin{array}{l}\text { 5. Sangsi } \\
\text { 1. Manipulasi catatan atau dokumen } \\
\text { 2. Pencatatan transaksi fiktif } \\
\text { 3. Sengaja menghilangkan transaksi } \\
\text { 4. Penyalahgunaan Aset } \\
\text { 5. Korupsi }\end{array}$ \\
\hline
\end{tabular}

Uji Instrumen berguna untuk mengukur valid atau tidaknya pertanyaan dalam kuisioner. Jika nilai rhitung $>$ rtabel maka dikatakan valid, namun saat nilai rhitung < rhitung maka dinyatakan tidak valid. Setelah dilakuakan uji validitas, kemudian akan dilakukan uji reliabilitas. Uji reliabilitas menggunakan cronbach's alpha, saat cronbach's alpha $>$ 0,6 maka instrumen dapat diterima atau reliabel.

Uji Asumsi Klasik berguna untuk melihat layak atau tidaknya model dan mengetahui apakah asumsi dalam model regresi berganda telah terpenuhi. Terdapat tiga asumsi yang harus terpenuhi diantarnya uji normalitas, uji multikolinearitas dan uji heterokedastisitas.
Uji Regresi Berganda (Pengujian Hipotesis) dilakukan untuk mengetahui pengaruh variabel terikat terhadap variabel bebas. Pengujian hipotesis dilakukan dengan t-test. Saat nilai sig $<0,05$ atau thitung $>$ ttabel maka hipotesis diterima. Adapun persamaan regresinya sebagai berikut:

$$
\mathrm{Y}=\mathrm{a}+\mathrm{b} 1 \mathrm{X} 1+\mathrm{b} 2 \mathrm{X} 2+\mathrm{b} 3 \mathrm{X} 3+\mathrm{b} 4 \mathrm{X} 4+\mathrm{e}
$$
Dimana:

Y : Kecurangan akuntansi

a : Konstanta

X1 : Ketaatan aturan akuntansi

X2 : Kontrol atasan

X3 : Budaya etis organisasi

X4 : Penegakan hukum

B1,2,3,4 : Koefisien regresi

e : Variabel yang tidak diteliti 


\section{Hasil Penelitian dan Pembahasan}

Penelitian ini memiliki jumlah target populasi sebanyak 30 Organisasi Perangkat Daerah dengan responden sebanyak 60 , tetapi hanya didapatkan sebanyak 54 responden dari 30 Organisasi Perangkat Daerah di Kota Salatiga. Berikut adalah karakteristik responden yang dapat dilihat di tabel 2 .

Tabel 2. Karakteristik Responden

\begin{tabular}{llcc}
\hline \multicolumn{1}{c}{ Karakteristik } & \multicolumn{1}{c}{ Kategori } & Jumlah & Prosentase \\
\hline Usia & $<20$ tahun & 0 & 0 \\
& $21-40$ tahun & 32 & 59 \\
& $41-60$ tahun & 22 & 41 \\
\hline \multirow{2}{*}{ Jenis Kelamin } & Laki-laki & 20 & 37 \\
& Perempuan & 34 & 63 \\
\hline \multirow{2}{*}{ Pendidikan Terakhir } & SMA & 6 & 11 \\
& Diploma 3 & 9 & 17 \\
& Strata 1 & 33 & 61 \\
& Strata 2 & 6 & 11 \\
& Strata 3 & 0 & 0 \\
& Lainnya & 0 & 0 \\
\hline Jabatan & Staf keuangan & 54 & 100 \\
\hline Masa Jabatan & $<5$ tahun & 6 & 11 \\
& 5-10 tahun & 16 & 30 \\
& $>10$ tahun & 32 & 59 \\
\hline
\end{tabular}

Sumber : Data primer yang diolah (2019)

Berdasarkan tabel 2 dapat dilihat bahwa usia sfat keuangan di seluruh Organisasi Perangkat Daerah di Kota Salatiga sebagian besar berada pada kelompok usia 21-40 tahun yaitu sebanyak 32 responden (59\%), hal ini menggambarkan bahwa mayoritas staf keuangan dalam usia yang produktif. Selain itu staf keuangan berjenis kelamin perempuan lebih mendominasi yaitu sebesar 43 orang atau $(63 \%)$ daripada laki-laki yang hanya memiliki prosentase $(37 \%)$ atau sebanyak 20 orang. Mayoritas pendidikan terakhir staf keuangan dalam penelitian ini adalah srata 1 (S1) atau sebanyak 33 orang dengan prosentase (61\%). Tabel 2 mengindikasikan bahwa kebanyakan staf keuangan telah bekerja lebih dari 10 tahun yang artinya staf keuangan dalam penelitian ini telah memiliki pengalaman yang cukup banyak dalam menyelesaikan kegiatan akuntansi dalam instansi yang bersangkutan.

\section{Statistik Deskritif Variabel Penelitian}

Pada penelitian ini untuk melihat hasil jawaban responden yang telah didapatkan, Berikut akan dijabarkan statistik deskriptif dari masing-masing variabel yang dapat dilihat pada Tabel 3 .

Tabel 3. Statistik Deskriptif Variabel-Variabel Penelitian

\begin{tabular}{lccccc}
\hline \multicolumn{1}{c}{ Variabel } & N & Minimum & Maximum & Mean & $\begin{array}{c}\text { Std. } \\
\text { Deviasi }\end{array}$ \\
\hline Ketaatan Aturan Akuntansi & 54 & 21 & 34 & 27,85 & 3,36 \\
Kontrol atasan & 54 & 12 & 15 & 13,37 & 0,97 \\
Budaya Etis Organisasi & 54 & 18 & 25 & 20,61 & 1,58 \\
Penegakan Hukum & 54 & 11 & 13 & 12,09 & 0,78 \\
Kecurangan Akuntansi & 54 & 21 & 42 & 28,33 & 3,00 \\
\hline
\end{tabular}

Sumber : Data primer (diolah 2019) 
Pada tabel 3 menunjukan variabel ketaatan aturan akuntansi memiliki rata-rata skor 27,85 dengan nilai terendah 21 dan nilai tetinggi 34, dengan nilai standar deviasi 3,36. Rata-rata jawaban dari variabel kontrol atasan adalah 13,37 dari nilai terendah 12 dan tertinggi 15 , dengan stansar deviasi untuk variabel kontrol atasan memiliki nilai 0,97. Berdasarkan tabel 3 rata-rata responden merasa budaya etis organisi memiliki nilai rata-rata sebesar 20,61 dari nilai terendah 18 dan tertinggi 25. Nilai penegakan hukum terendah adalah sebesar 11 dan nilai tertinggi 13. Dengan rata-rata 12,09 serta standar deviasi 0,78. Yang terakhir variabel kecurangan akuntansi dengan rata-rata 28,33 dengan nilai terendah 21 dan nilai tertinggi 42, serta nilai standar deviasi sebesar 3,00.

\section{Uji Validitas}

Tabel 4. Hasil Uji Validitas

\begin{tabular}{|c|c|c|c|}
\hline Variabel & $\begin{array}{lr}\text { Nilai } & R \\
\text { Hitung } & \end{array}$ & $\begin{array}{ll}\text { Nilai } & R \\
\text { Tabel } & \end{array}$ & Keterangan \\
\hline \multicolumn{4}{|c|}{ Ketaatan Aturan Akuntansi } \\
\hline $\mathrm{X} 1.1$ & 0,272 & 0,266 & Valid \\
\hline $\mathrm{X} 1.2$ & 0,575 & 0,266 & Valid \\
\hline $\mathrm{X} 1.3$ & 0,611 & 0,266 & Valid \\
\hline $\mathrm{X} 1.4$ & 0,568 & 0,266 & Valid \\
\hline $\mathrm{X} 1.5$ & 0,436 & 0,266 & Valid \\
\hline $\mathrm{X} 1.6$ & 0,520 & 0,266 & Valid \\
\hline $\mathrm{X} 1.7$ & 0,579 & 0,266 & Valid \\
\hline \multicolumn{4}{|c|}{ Kontrol Atasan } \\
\hline $\mathrm{X} 2.1$ & 0,951 & 0,266 & Valid \\
\hline $\mathrm{X} 2.2$ & 0,943 & 0,266 & Valid \\
\hline $\mathrm{X} 2.3$ & 0,931 & 0,266 & Valid \\
\hline \multicolumn{4}{|c|}{ Budaya etis organisasi } \\
\hline $\mathrm{X} 3.1$ & 0,789 & 0,266 & Valid \\
\hline $\mathrm{X} 3.2$ & 0,635 & 0,266 & Valid \\
\hline $\mathrm{X} 3.3$ & 0,720 & 0,266 & Valid \\
\hline \multicolumn{4}{|c|}{ Penegakan Hukum } \\
\hline $\mathrm{X} 4.1$ & 0,603 & 0,266 & Valid \\
\hline $\mathrm{X} 4.2$ & 0,894 & 0,266 & Valid \\
\hline $\mathrm{X} 4.3$ & 0,870 & 0,266 & Valid \\
\hline $\mathrm{X} 4.4$ & 0,756 & 0,266 & Valid \\
\hline $\mathrm{X} 4.5$ & 0,756 & 0,266 & Valid \\
\hline \multicolumn{4}{|c|}{ Kecurangan Akuntansi } \\
\hline Y1.1 & 0,335 & 0,266 & Valid \\
\hline $\mathrm{Y} 1.2$ & 0,554 & 0,266 & Valid \\
\hline Y1.3 & 0,507 & 0,266 & Valid \\
\hline Y1.4 & 0,578 & 0,266 & Valid \\
\hline Y1.5 & 0,491 & 0,266 & Valid \\
\hline Y1.6 & 0,657 & 0,266 & Valid \\
\hline Y1.7 & 0,712 & 0,266 & Valid \\
\hline Y 1.8 & 0,508 & 0,266 & Valid \\
\hline Y1.9 & 0,540 & 0,266 & Valid \\
\hline Y1.10 & 0,539 & 0,266 & Valid \\
\hline
\end{tabular}

Sumber : Data primer (diolah 2019) 
Hasil perhitungan Tabel 4 menunjukkan pertanyaan di kuisioner yang disajikan untuk masing-masing variabel memiliki nilai $r$ hitung $>\mathrm{r}$ Tabel sehingga dari hasil tersebut dapat ditarik kesimpulan semua item pertanyaan yang ada didalam kuesioner dapat dinyatakan valid.

\section{Uji Reliabilitas}

Tabel 5. Hasil Uji Reliabilitas

\begin{tabular}{llr}
\hline Variabel & Cronbach Alpha & Keterangan \\
\hline Ketaatan Aturan Akuntansi & 0,687 & Reliabel \\
Kontrol atasan & 0,874 & Reliabel \\
Budaya Etis Organisasi & 0,780 & Reliabel \\
Penegakan Hukum & 0,792 & Reliabel \\
Kecurangan Akuntansi & 0,722 & Reliabel \\
\hline
\end{tabular}

Sumber : Data primer (diolah 2019)

Dari tabel 5 di atas menunjukan bahwa seluruh instrument penelitian mempunyai nilai diatas 0,60 yang artinya instrumen tersebut dapat dinyatakan reliabel.

\section{Uji Asumsi Klasik}

Uji normalitas dilakukan dengan menggunakan One Sample KolmogorovSmirnov Test. Nilai signifikan dalam penelitian ini adalah $0,563>0,05$ yang bermakna bahwa distribusi data residual adalah normal karena melebihi standar 0,05.Dalam penelitian ini mempunyai nilai VIF (Variance Inflating Factor) dibawah angka 10 Mempunyai angka tolerance dibawah angka 1, sehingga disimpulkan model regresi tersebut tidak terdapat multikolinieritas antara variabel bebasnya. Sedangkan berdasarkan hasil pengujian heteroskedastisitas diketahui bahwa titik-titik yang terbentuk pada grafik scaterplot (terdapat pada lampiran) tidak membentuk pola yang jelas serta tersebar di atas dan di bawah angka 0 pada sumbu $Y$ sehingga disimpulan bahwa model regresi yang digunakan bebas heteroskedastisitas.

\section{Uji Hipotesis}

Pengujian hipotesis berguna untuk melihat pengaruh ketaatan aturan akuntansi, kontrol atasan, budaya etis organisasi dan penegakan hukum terhadap kecurangan akuntansi dengan menggunakan uji regresi berganda.

Tabel 6. Hasil Uji Hipotesis

\begin{tabular}{lllll}
\hline Variabel & T & Sig & $\begin{array}{l}\text { Standardized } \\
\text { Coefficients Beta }\end{array}$ & Keterangan \\
\hline $\begin{array}{l}\text { Ketaatan aturan } \\
\text { akuntansi }\end{array}$ & $-2,097$ &, 041 &,- 236 & H1 diterima \\
\hline Kontrol ataasan & $-2,297$ &, 026 &,- 256 & H2 diterima \\
\hline $\begin{array}{l}\text { Budaya etis } \\
\text { organisasi }\end{array}$ & $-3,129$ &, 003 &,- 343 & H3 diterima \\
\hline $\begin{array}{l}\text { Penegakan hukum } \\
\mathrm{R}^{2}\end{array}$ & $-2,546$ &, 014 &,- 284 & H4 diterima \\
\hline
\end{tabular}

Sumber : Data primer (diolah 2019) 
Berdasarkan tabel diatas diketahui ketaatan aturan akuntansi berpengaruh negatif signifikan terhadap kecurangan akuntansi. Dilihat dari hasil nilai t hitung sebesar -2,097 dengan angka signifikan 0,041<0,05 dengan demikian H1 diterima. Kontrol atasan berpengaruh negatif serta signifikan terhadap kecurangan akuntansi. Dilihat dari nilai $t$ sebesar -2,297 dengan angka signifikan 0,026 $<0,05$ sehinga $\mathrm{H} 2$ diterima.

Pada tabel diatas menunjukan budaya etis organisasi berpengaruh negatif dengan nilai t hitung -3,129 dengan nilai signifikan 0.003 yang lebih kecil dari 0,05 . Sehingga H3 menyatakan budaya etis organisasi berpengaruh negatif terhadap kecurangan akuntansi. Sehingga H3 diterima. Hipotesis yang terakhir, penegakan hukum menunjukkan nilai signifikansi sebesar 0,014 yang mana lebih kecil dari pada 0,05 dengan nilai t hitung $-2,546$ sehingga hipotesis dapat diterima. Jadi, disimpulkan semakin tegaknya peraturan/hukum, maka tingkat kecurangan akuntansi akan berkurang.

Hasil perhitungan $R^{2}$ adalah sebesar 0,374, sehingga variabel Ketaatan aturan akuntansi, Kontrol atasan, Budaya etis organisasi dan Penegakan hukummampu menjelaskan Kecurangan akuntansi sebesar $37,4 \%$ sedangkan sisanya sebesar $62,6 \%$ dijelaskan oleh variabel lain yang tidak diteliti dalam penelitian ini.

\section{Pembahasan}

\section{Pengaruh Ketaatan Aturan Akuntansi Terhadap Kecurangan Akuntansi}

Berdasarkan pengujian hipotesis, variabel ketaatan aturan akuntansi memiliki pengaruh negatif dengan nilai signifikan sebesar 0,041 . Berarti makin taat suatu organisasi terhadap aturan akuntansi maka kecurangan akuntansi akan semakin bekurang. Ketaatan lahir dari diri individu sendiri yang mendorong seseorang untuk melakukan sebuah tindakan. Tindakan tersebut merujuk pada sesuatu yang akan didapat individu atau keuntungan yang mungkin diterima. Seorang individu akan memiliki niat untuk taat terhadap aturan akuntansi saat ia beranggapan bahwa tindakan yang tidak sesuai aturan hanya akan merugikan diri sendiri. Ketaatan terhadap aturan akuntansi yang dimiliki seorang pegawai dalam sebuah organisasi merupakan kunci keberhasilan dalam mengurangi kecurangan akuntansi. Semakin baik tingkat ketaataan terhadap aturan akuntansi yang dimiliki seorang pegawai maka peluang terjadinya kecuragan akan semakin berkurang. Hal tersebut sejalan dengan penelitian Shintadevi (2015) dan Ade (2017)mengenai ketaatan aturan akuntansi yang menyatakan penyusunan laporan keuangan, jika dilakukan sesuai peraturan yang ada dengan hati-hati maka akan mengurangi kecurangan.

\section{Pengaruh kontrol atasan terhadap kecurangan akuntansi}

Uji hipotesis terhadap kontrol atasan terbukti bahwa kontrol atasan memiliki pengaruh negatif serta signifikan terhadap kecurangan akuntansi. Dilihat dari nilai $t$ sebesar -2,297 dengan angka signifikan 0,026 $<0,05$, sehingga semakin baik kontrol atasan maka semakin berkurang kecurangan akuntansi. Dengan memberikan arahan atas setiap pekerjaan bawahan, menciptakan komunikasi yang baik dengan bawahan serta melakukan pemerikasaan atas pekerjaan bawahan akan menumbuhkan mental yang baik bagi bawahan sehingga kemungkinan terjadi kecurangan akan berkurang.Kontrol yang dilakukan atasan dapat membuat kinerja pegawai berjalan sesuai dengan aturan yang berlaku, mengurangi kesulitan yang mungkin dihadapi serta mempengaruhi seseorang pegawai dalam bertindak. Semakin baik kontrol yang dilakukan atasan akan membuat bawahan berperilaku sebagaimana mestinya dan enggan untuk berperilaku tidak sesuai aturan sehingga kecurangan dapat dikurangi. (Soleha, Komara, \& Sudia, 2012).

\section{Pengaruh budaya etis organisasi terhadap kecurangan akuntansi}

Uji hipotesis menunjukan budaya etis organisasi berpengaruh negatif dengan nilai $\mathrm{t}$ hitung $-3,129$ dengan nilai signifikan 0.003. Artinya semakin baik budaya etis dalam sebuah organisasi maka kecurangan akuntansi akan berkurang. Penerapan budaya etis dalam sebuah organisasi dapat membuat seseorang inividu melakukan tindakan sesuai etika 
sehingga kecurangan akuntansi dapat diminimalisir. Budaya organisasi merupakan pemaknaan serta sistem yang dipegang oleh anggota dalam suatu organisasi, yang mana berisikan nilai-nilai serta norma yang membentuk karakter dan mempengaruhi cara kerja dan berperilaku seseorang dalam berorganisasi. Di dalam organisasi yang menerapkan budaya etis, seorang pegawai akan cenderung berperilaku etis atau melakukan tindakan-tindakan beretika dan dapat menghindari kecurangan (Artini, Adiputra dan Herawati, 2014).

Dengan berkembang budaya etis yang maka seorang pegawai akan merasa enggan untuk melakukan kegiatan yang menyimpang karena telah terbiasa dengan budaya etis yang baik yang diterapkan dalam organisasi. Hal ini selaras dengan penelitian yang telah dilaksanakan oleh Pramudita(2013) dan Yuliani (2018) yang menjelaskan semakin baik budaya etis dalam sebuah organisasi, maka kecendrungan pegawai untuk melakukan kecurangan akan semakin rendah.

\section{Pengaruh penegakan hukum terhadap kecurangan akuntansi}

Setelah melakukan pengujian, hasil penelitian terhadap penegakan hukum menunjukkan nilai signifikansi sebesar 0,014 yang mana lebih kecil dari pada 0,05 dengan nilai t hitung -2,546 sehingga hipotesis dapat diterima. Ketidaksadaran akan pentingnya menaati hukum atau kurangnya penegakan hukum dapat menyebabkan kecurangan, oleh karena itu penegakan hukum akan meningkatkan kesadaran untuk mematuhi peraturan atau hukum yang diterapkan dalam organisasi, sehingga kecurangan dapat dikurangi.

Hukum yang bersifat memaksa dengan pegawai yang sedari awal memahami pentingnya menaati hukum dan tindakan yang tegas dari pihak berwenang dalam organisasi akan membuat siapapun yang melanggar hukum akan terkena sangsi. Hasil tersebut didukung oleh penelitian Didi (2018) dan Sari (2018) yang mengatakan penegakan hukum ditentukan oleh komitmen pihak berwenang dalam organisasi yang harus konsisten dan tegas bagi para pelanggar peraturan. semakin tinggi persepsi pegawai akan pentingnya penegakan hukum, maka akan mengurangi terjadinya kecurangan akuntansi.

\section{Kesimpulan, Keterbatasan Dan Implikasi Hasil Penelitian}

Berdasar hasil penelitian ini dapat disimpulkan bahwa ketaatan aturan akuntansi, budaya etis organisasi, dan penegakan hukum terbukti berpengaruh negatif signifikan terhadap kecurangan akuntansi di Organisasi Perangkat Daerah Kota Salatiga. Hal ini menunjukkan bahwa semakin taat seorang pegawai terhadap aturan akuntansi, kontrol dari atasan yang semakin baik, dengan budaya etis yang tumbuh dengan baik di suatu organisasi, serta hukum yang semakin ditegakkan di dalam organisasi akan membuat kecuangan akuntansi semakin berkurang.

Data dalam penelitian ini merupakan data primer berupa kuisioner. Keterbatasan menggunakan data berupa kuisioner adalah keterangan dari responden yang kurang detail karena hanya terpaku pada pertanyaan pada kuisioner sehingga ada kemungkinan persepsi responden berbeda dengan keadaan sesungguhnya yang mengakibatkan keakuratan informasi kurang. Selanjutnya keterbatasan penelitian ini adalah lamanya kuisioner dapat terkumpul karena kesibukan setiap dinas dan lokasi OPD yang berbedabeda sehingga data penelitian ini memakan waktu yang cukup lama.

Saran secara teknis untuk hasil temuan penelitian, masih terdapat beberapa responden yang kurang mengerti akan pentingnya menaati aturan serta hukum yang berlaku, sehingga diharapkan pihak yang berwenang dalam hal ini kepala organisasi untuk lebih tegas akan penegakan aturan atau hukum yang berlaku, disertai pengawasan atau kontrol yang semakin intensif atas kinerja bawahan. Kemudian berupaya menanamkan kebiasaan baik dengan berperilaku etis yang kemudian akan dicontoh oleh pegawai di dalam organisasi terkait. Saran untuk penelitian mendatang dapat lebih rinci memberikan pertanyaan kepada responden didalam kuisioner yang digunakan, serta melakukan wawancara agar informasi yang didapatkan semakin akurat. 


\section{Daftar Pustaka}

Ade, A. (2017). Pengaruh Ketaatan Akuntansi, Moralitas Dan Motivasi Terhadap Kecenderungan Kecurangan Akuntans. 1-24.

Adelin, V. (2013). Pengaruh Pengendalian Internal,Ketaatan Aturan Akuntansi, dan Perilaku Tidak Etis Terhadap Kecenderungan Kecurangan Akuntansi. 122.

Amalia, R. D. (2015). Pengaruh Keefektifan Pengendalian Internal, Kesesuaian Kompensasi, Moralitas Aparat Dan Asimetri Informasi Terhadap Kecenderungan Kecurangan Akuntansi. Jom FEKON, No.2 Vol. 2, 1-15.

Aranta, P. Z. (2013). Pengaruh Moralitas Aparat dan Asimetri Informasi Terhadap Kecenderungan Kecurangan Akuntansi. 128.

Arisandy, D. (2004). Hubungan Antara Persepsi Karyawan Terhadap Disiplin Kerja Karyawan Bagian Produksi Pabrik Keramik "Ken Lila Production” Di Jakarta. Psyche, No. 2 Vol.1, 23-34.

Artini, N. L., Adiputra, I. M., \& Herawati, N. T. (2014). Pengaruh Budaya Etis Organisasi Dan Efektivitas Pengendalian Internal Terhadap Kecenderungan Kecurangan Akuntansi Pada Satuan Kerja Perangkat Daerah (Skpd) Kabupaten Jembrana. Jurnal Universitas Pendidikan Ganesha Jurusan Akuntansi S1, No.1 Vol.2, 1-9.

Didi. (2018). Faktor-Faktor Yang Berpengaruh Terhadap Kecenderungan Kecurangan (Fraud): Persepsi Pegawai Pemerintahan Daerah Kota Bogor. Jurnal Akuntansi dan Keuangan Indonesia, Vol 15 No 1, 1-20.

Faisal, M. (2013). Analisis Fraud Di Sektor Pemerintahan Kabupaten Kudus. Jurnal Analisis Akuntansi, 68-73.

Indriastuti, D. E., Agusdin, \& Aminah. (2016). Analisis Pengaruh Asimetri Informasi, Pengendalian Internal, Persepsi Kesesuaian Kompensasi, Moralitas Individu, Dan Ketaatan Aturan Akuntansi
Terhadap Kecurangan Akuntansi. Infestasi, 115-130.

Noviriantini, K., Darmawan, N. A., \& Werastuti, D. N. (2015). Pengaruh Budaya Etis Organisasi Dan Moralitas Aparat Terhadap Kecenderungan Kecurangan (Fraud) Akuntansi (Studi Empiris Pada Satuan Kerja Perangkat Daerah Kabupaten Jembrana. Jurusan Akuntansi Program S1, No. 1 Vol.3, 1-12.

Pramudita, A. (2013). Analisis Fraud Di Sektor Pemerintahan Kota Salatiga. Accounting Analysis Journal, No.3 Vol.1, 36-43.

Rizky, M., \& Fitri, F. A. (2017). Pengaruh Keefektifan Pengendalian Internal, Ketaatan Aturan Akuntansi, Penegakan Hukum, Dan Perilaku Tidak Etis Terhadap Kecurangan Akuntansi. Jurnal Ilmiah Mahasiswa Ekonomi Akuntansi (JIMEKA), No. 2 Vol.2, 10-20.

Sari, R. N. (2018). Pengaruh Budaya Etis Organisasi, Penegakan Hukum Dan Asimetri Informasi Terhadap Kecendrungan Kecurangan Akuntansi (Fraud). 1-20.

Shintadevi, p. f. (2015). Pengaruh Keefektifan Pengendalian Internal, Ketaatan Aturan Akuntansi Dan Kesesuaian Kompensasi Terhadap Kecenderungan Kecurangan Akuntansi Dengan Perilaku Tidak Etis Sebagai Variabel Intervening. Jurnal nominal, Vol IV No 2.

Soleha, L. K., Komara, A. T., \& Sudia, Y. (2012). Pengaruh Kepemimpinan, Disiplin Kerja, Dan Komunikasi Terhadap Kinerja Pegawai Sekretariat Komisi Penyiaran Indonesia Daerah Provinsi Jawa Barat. Jurnal Ekonomi, Bisnis \& Entrepreneurship, No.1 Vol.6, 39-50.

Sumbayak, J. S. (2017). Pengaruh Keadilan Organisasi, Sistem Pengendalian Intern, Komitmen Organisasi Dan Gaya Kepemimpinan Terhadap Kecurangan (Fraud). JOM Fekon, No. 1 Vol 4., 31683182.

Tunggal , A. (2012). Pedoman Pokok Audit Internal. Jakarta: Harvarind. 
Intan Putri Estikasari, Priyo Hadi Adi : Ketaatan Akuntansi, Kontrol Atasan, Budaya Etis Organisasi, Penegakan Hukum dan Kecurangan Akuntansi

Yuliani, S. (2018). Pengaruh Perilaku Tidak Etis, Pengendalian Internal dan Budaya Organisasi Terhadap Kecenderungan Kecurangan Akuntansi. 1-21. 